\title{
Evaluation of Polyphenols Enriched Dairy Products Developed by Incorporating Black Carrot (Daucus carota L.) Concentrate
}

pragya pandey

Funding: The author(s) received no specific funding for this work.

Potential competing interests: The author(s) declared that no potential competing interests exist.

\section{Abstract}

Background: Dairy products like ice cream, yogurt and buttermilk are consumed widely due to their rich taste but these products lack anthocyanins, which are polyphenol and exhibit great antioxidant activity in both in vivo and in vitro studies. Therefore, adding a natural source of these antioxidants to the commonly consumed dairy product will be beneficial to the masses. Among all the sources, black carrots are the extraordinary and cheapest source of anthocyanins, which are commonly consumed as a natural fermented drink. In this study, an attempt has been made to examine the feasibility of black carrot concentrate as an ingredient into dairy products.

Methodology: Ice cream, yogurt and buttermilk were prepared by incorporating black carrot concentrate at 2.5, 5.0, 7.5 and $10 \%$ level and were subjected to sensory analysis. The most acceptable products with $7.5 \%$ black carrot concentrate were analyzed for minerals, polyphenols and antioxidant activity. Effects of storage on physicochemical, microbial and sensory attributes of black carrot concentrate incorporated dairy products were further analyzed.

Results: Sensory analysis revealed that black carrot concentrate could be used up to $7.5 \%$ as an ingredient into dairy product with high acceptability. Significant improvement in mineral content ( $\mathrm{Mg}$ and Fe), polyphenols and antioxidant activity were reported in black carrot concentrate added dairy products. Developed dairy products exhibited an excellent amount of 24.52 to $113.27 \mathrm{mg} / 100 \mathrm{~g}$ anthocyanins. Flavonoids increased by 14.52 to 34.62 times and Folin-Ciocalteu reducing capacity increased by 26.39 to 35.87 times in experimental dairy products. The storage study revealed that ice cream could be stored for more than 60 days, yogurt up to 5 days and buttermilk up to 10 days with excellent stability attributes.

Conclusion: Incorporation of black carrot concentrate at the level of 7.5\% resulted in high acceptability and exceptional nutraceutical property of dairy products. Incorporation of black carrot concentrate into dairy products would enhance the nutraceutical properties and mineral content of food, which could be highly significant in preventing hidden hunger and oxidative stress-induced disorders in developing countries.

Keywords: Black Carrot Concentrate, Functional Food, Anthocyanins, Ice-cream, Yogurt, Buttermilk 


\section{Introduction}

Antioxidants are widely used in the food industry as synthetic food additives to enhance the stability of fats by preventing their oxidative deterioration. Lately, there has been a growing interest in natural antioxidants and their impact on health and disease prevention. India is witnessing an accelerated rise in the prevalence of oxidative stress-induced diseases like hypertension, diabetes, CVD and cancer (Uttara et al 2009). Free radicals are generated due to various physiological conditions which have a hostile effect on the intestinal epithelium cells. Free radical damage to biological molecules such as lipids, proteins and nucleic acids is considered to be linked to a variety of degenerative diseases that are the leading causes of disability and death in India. Their contribution to the burden of disease is expected to increase over the next 25 years (Patel et al 2011).

A great number of fruits and vegetables, spices and medicinal plants contain bioactive components demonstrating free radical scavenging activity. Bioactive compounds especially polyphenols are said to have a major role in the reduction of oxidative stress. Polyphenols are regarded as secondary metabolites, which does not demonstrate any specific metabolic properties in plant cells (Xiao et al 2015), but are essential for the nutritional and sensory characteristics of plant foods. Epidemiological and nutrition studies have shown that polyphenols have a significant role in the prevention of oxidative stress-induced diseases such as diabetes, cancer and heart diseases (Pandey and Grover 2020, Costa et al 2017, Pandey and Rizvi 2009). Polyphenols have been exhibited to show a wide range of physiological benefits as free radical scavenging activity, anti-inflammatory, anti-tumor and anti-diabetic characteristics (Xiao et al 2014, Xiao et al 2014a). Lately, there has been a growing focus on novel antioxidants originated from natural sources. Fruits and vegetables are gaining wide attention pertaining to their richness in different categories of polyphenols (Nabavi et al 2013). Black carrot is a common Indian root vegetable, which can be easily cultivated during the winter season. This crop is a tremendous source of anthocyanin pigments and is extremely high in polyphenols. It has depicted exceptionally great antioxidant potential in both in-vitro and in-vivo studies (Narayan and Vankataraman 2000, Karakaya et al 2001, Kaur and Kapoor 2002, Glei et al 2003, Ravindra and Narayan 2003, Uyan et al 2004). Punjab Agricultural University (PAU), Ludhiana has developed India's second black carrot variety 'Punjab Black Beauty' for the benefits of farmers, which also promises to address the needs of a huge malnourished section of the Indian population. Black carrots are considered to be the cheapest source of anthocyanin as this crop is available at a very low price (8-15 Rs/kg) in India. Black carrots are grossly underutilized and do not receive much consumer acceptance as a vegetable despite having the obvious advantages as a source of natural food colourant, natural antioxidant and rich mineral content. Despite having numerous health benefits, not enough research work is being done to promote the utilization of black carrots in the food sector. Dairy products are an integral part of the human diet throughout the globe. It posses an abundant amount of nutrients such as proteins, calcium and vitamins. India is one of the leading producer and consumer of dairy products in the world. Fruit fortified dairy products are already in the market and are highly accepted by consumers. Dairy products can be effectively used as food carriers for natural colourant derived from black carrot polyphenols and anthocyanins. Keeping in mind the wide availability of dairy products in the Indian population, this study was undertaken to develop polyphenols enriched dairy products such as ice cream, yogurt and buttermilk using black carrot concentrate. The addition of black carrot 
concentrate as a natural food additive will not only enhance the polyphenol content in the diet but will also help to improve the utilization of black carrots.

\section{Materials and methods}

Punjab Agricultural University, Ludhiana has developed India's second black carrot variety 'Punjab Black Beauty' as a solution for preventing hidden hunger and oxidative stress-induced disorders in developing countries like India. Black carrot concentrate of 'Punjab black beauty' variety was obtained from Pun-juice Punjab Agro factory, Hoshiarpur, Punjab. The other ingredients used for product development were obtained from the local market of Ludhiana, Punjab.

\subsection{Preparation of dairy products}

Three dairy products namely ice cream, yogurt and buttermilk were developed for this study by using black carrot concentrate as an ingredient. The ice cream was developed by the method of Hashim and Shamsi (2016). Ingredient used were fresh whole milk (250 ml), whipped cream (200 g), sugar, (70 g), skim milk powder (30g) and cornflour (15 g). The ice cream samples were prepared in triplicate. Milk was boiled in a non-stick pan. Corn flour was mixed in two tablespoons of water and then added to the boiling milk. It was stirred continuously for two to three minutes. Then sugar and milk powder was incorporated and mixed properly to avoid the development of lumps. The mixture was then transferred from a muslin cloth into the container and froze in a deep freezer for 2 hours. The cream was added in order to achieve its fat content to $5 \%$. The prepared mixture was divided into four equal batches. One batch was treated as control and the experimental batches were prepared by substituting cream added mixture with pasteurized black carrot concentrate at different levels $(0$, 5.0, 7.5 and $10 \%)$. The ice cream was collected and then filled in small cups and stored at $-20^{\circ} \mathrm{C}$ till analyzed. Yogurt was developed with the method described by De (2006). Yogurt culture NCDC 144 (L. delbrukii subspbulgaricus and S. thermophiles, 1:1) was procured from NDRI, Karnal. Milk was preheated to $35-40^{\circ} \mathrm{C}$, filtered to remove extraneous matter. Skim milk powder was added to milk to adjust the solids-not-fat content to approximately $12-15 \%$. This mixture was preheated to $60^{\circ} \mathrm{C}$ and homogenized. The contents and black carrot concentrate was pasteurized to $90^{\circ} \mathrm{C}$ for 30 minutes, after that the temperature was brought down to $43-44{ }^{\circ} \mathrm{C}$. The mixture was then inoculated with $2 \%$ bulk starter and stirred briefly to ensure proper mixing. The mix was filled into packages taking care that the temperature does not fall below $41^{\circ} \mathrm{C}$ during the filling operation. It was made sure that the time interval between inoculation and filling do not exceed 45 min. The packages were incubated without further agitation at $42^{\circ} \mathrm{C}$ for about $4-5$ hours, till a titrable acidity of $0.75 \%$ was reached. Then it was placed under refrigeration to cool to $5-7^{\circ} \mathrm{C}$. The black carrot concentrate enriched yogurt samples were processed similarly as control however, pasteurized black carrot concentrate at the selected percentage $(0 \%, 5.0 \%$, 7.5 and $10 \%$ ) was added prior to the addition of culture to these samples.

For the preparation of buttermilk, double toned milk was purchased from Verka Dairy, Ludhiana, Punjab, India and stored at $4{ }^{\circ} \mathrm{C}$. A bacterial culture NCDC 144 (L. delbrukii subspbulgaricus and S. thermophiles, 1:1) was procured from NDRI, Karnal and stored at $-18{ }^{\circ} \mathrm{C}$ until used. The milk was constituted of $1.5 \%$ fat and $9.0 \%$ SNF. The milk was heated to $42{ }^{\circ} \mathrm{C}$ followed by inoculation with culture. The culture was thoroughly mixed into the milk. The inoculated milk was then shifted to the pre-sterilized beakers with lids of 1 -litre capacity. The yogurt samples were incubated at $42{ }^{\circ} \mathrm{C}$ in an incubator for 7 hours for proper fermentation. After the desired curd setting, the curd was subjected to agitation for 90 seconds at 10,000 rpm using a blending machine (CelloBlend-N-Mix300, India). Finally, pasteurized cold water was added thoroughly homogenized. Black carrot concentrate incorporated buttermilk sample treatments were processed in the same fashion as 
control except the step involving the addition of pasteurized black carrot concentrate at a selected percentage $(0 \%, 5.0 \%$, 7.5 and $10 \%$ ) prior to the addition of culture (Fig 1).

\subsection{Sensory Analysis}

A panel of 10 trained members was formed who were between the age group 22 to 55 years, and medically fit to perform sensory analysis. Informed consent was obtained from all the panel members before evaluation. The panel members were selected from the Department of Food and Nutrition, Punjab Agricultural University, Ludhiana. The formulated treatments were evaluated fresh as well as during storage for sensory attributes using 9 point hedonic scale (Larmond, 1970) (Annexure I, II and III).

\subsection{Determination of Physicochemical properties}

Formulated products were assessed for total soluble solids (TSS), titratable acidity and pH. TSS content was determined by using a hand refractometer (Erma, Japan) with scale ranging from 0 to $32^{\circ}$ Brix. The observations were expressed as ${ }^{\circ}$ Brix at $20^{\circ} \mathrm{C}$. The titratable acidity was determined according to the method of (Ranganna 2007). The pH was evaluated with the help of a digital pH meter.

\subsection{Determination of Minerals}

Developed products were assessed for mineral content viz. magnesium, zinc and iron (Piper 1950).

\subsection{Determination of Anthocyanins, Flavonoids content and Folin-Ciocalteu reducing capacity}

Total anthocyanin content of the samples was estimated by the method of Rabino et al (1977). A fresh sample of $1 \mathrm{~g}$ was taken and crushed finely. $10 \mathrm{ml}$ of $1 \%$ methanolic $\mathrm{HCl}(\mathrm{w} / \mathrm{v})$ was added and it was kept overnight at $4{ }^{\circ} \mathrm{C}$. The next day, sample extracts were filtered and absorbance was taken at 530 and $657 \mathrm{~nm}$. The total anthocyanin content of the sample extract was calculated using the formula $A_{530}-0.33 A_{657}$. This formula is used to correct for the contribution of chlorophyll and its degradation products in acid solution to the absorbance of extracts at $530 \mathrm{~nm}$ (Mancinelli et al 1975). The total anthocyanin content was expressed as cyanidin 3-glucoside (Cyd 3-glu) $\mathrm{mg} / 100 \mathrm{~g}$ of the fresh sample weight. The estimation of total flavonoids was done by the assay described by Zhishen et al (1999) and results were expressed as catechin equivalents (CE) /100g of fresh sample.

Folin-Ciocalteu reducing capacity was analysed using Folin-Ciocalteu assay by the method of Swain and Hillis(1959). The Folin-Ciocalteu (FC) assay is an electron transfer based assay that represents the reducing capacity of a sample. It is usually expressed as total phenols of the extract in the literature (Keskin-Šašić et al 2012, Vizzotto et al 2006, Marques 2012). Repeatable studies have reported that Folin-Ciocalteu assay is not exclusive to phenols as it can react with ascorbic acid, sodium bisulphite, reducing sugars, metals and reducing amino acids. As a result, this could deviate from the actual value of total phenolic content (Chen et al 2015). Considering the reaction of Folin-Ciocalteu reagent with nonphenolic substances present in the sample that can reduce the Folin-Ciocalteu reagent, this assay has been denominated as 'Folin-Ciocalteu reducing capacity'. This reaction takes place in the aqueous medium thus it determines the reducing capacity of water-soluble constituents in the sample (Granato et al 2016).

In brief, 1 gram of sample taken and it was refluxed with $80 \%$ methanol in a round bottom flask for 2 hours. and The extract was filtered and the residue was refluxed further for an additional 1 hour. The extract was collected and total volume was made to $100 \mathrm{ml}$ with $80 \%$ methanol. A sample extract of $0.5 \mathrm{ml}$ was taken in a test tube and $0.5 \mathrm{ml}$ of distilled water was added to it. Further, $5 \mathrm{ml}$ of FC reagent was added and this solution was kept at rest for 5 minutes. $1 \mathrm{ml}$ of saturated 
solution of sodium carbonate was added and the solution was stirred properly and kept at rest in a dark place for 60 minutes. The absorbance of the sample was measured at $725 \mathrm{~nm}$ using spectronic- 20 spectrophotometer. A standard curve was plotted against Gallic acid as standard. Folin-Ciocalteu reducing capacity was calculated as mg gallic acid equivalent (mg GAE/100g) of fresh sample.

\subsection{Determination of Total antioxidant activity:}

The chemical diversity of biological antioxidants makes it challenging to separate and measure individual oxidants from the food matrix. Therefore measurement of total antioxidant activity directly from food extract offers a viable alternative. In this study, two in vitro antioxidant assays namely ferric reducing antioxidant power (FRAP), 2,2-azinobis (3ethylbenzothiazoline)-6-sulfonic acid (ABTS) were performed by the methods described by Benzie and Strain (1996) and Miller and Rice-Evans (1997) respectively. In both assays, Trolox was used as a standard and the results were represented as $\mu \mathrm{mol}$ Trolox equivalent (TE) per gram fresh weight of the sample.

\subsection{Storage stability}

Experimental samples with $7.5 \%$ black carrot concentrate were analyzed to study the effect of storage on product stability and quality attributes. Ice cream samples were stored in $50 \mathrm{ml}$ airtight plastic cups at $-20^{\circ} \mathrm{C}$ for 60 days. The samples were analyzed for total solids (AOAC 2010), pH, acidity, total plate count (TPC), yeast and mould count (YMC) and sensory attributes at an interval of 15 days. Yogurt and buttermilk samples were stored for 15 days at $4^{0} \mathrm{C}$ in airtight plastic containers and glass bottles respectively and were evaluated for $\mathrm{pH}$, acidity and TPC, YMC and sensory characteristics at a regular interval of 5 days. Total Plate Count (TPC) and yeast and mould count (YMC) were evaluated as per the method described by David and Frankhausar (2015)

\subsection{Statistical analysis}

The results were expressed as mean \pm standard deviation. Data were analyzed by Kruskal Wallis $\mathrm{H}$-test for sensory analysis and student's t-test to analyze the difference between control and acceptable formulated experimental sample with $7.5 \%$ black carrot concentrate incorporation. Effect of storage on quality attributes of dairy products was analyzed by ANOVA (Analysis of variance), comparing average interval using the SPSS software, version 18.0 (Stats oft Inc. USA).

\section{Results and Discussion}

\subsection{Analysis of black carrot concentrate:}

Physicochemical, polyphenols, reducing capacity and total antioxidant activity of black carrot concentrate are presented in Table 1. The flavonoids, anthocyanins, Folin-Ciocalteu reducing capacity and total antioxidant activity of black carrot concentrate were exceptionally high as compared to the fresh black carrot. Flavonoids content in concentrate increased by 28 times with an excellent concentration of $1682.66 \mathrm{mg} / 100 \mathrm{~g}$ of anthocyanin. Analysis of Folin-Ciocalteu reducing capacity and total antioxidant capacity confirmed exceptionally high reducing capacity and antioxidant activity of black carrot concentrate.

\subsection{Sensory evaluation}

The hedonic test was used to assess the degree of liking of dairy products developed by using different levels of black carrot concentrate. The incorporation of black carrot concentrate imparted reddish-purple colour to the ice cream which was liked very much by the panellists. Ice cream with $7.5 \%$ black carrot concentrate showed the highest liking scores for its appearance and colour, which reduced significantly at $10 \%$ level. The texture, flavour, taste and overall acceptability of ice 
cream with black carrot concentrate at substitution levels of $0-7.5 \%$ depicted the highest liking score (Table 2).

Sensory evaluation of yogurt samples showed that appearance and colour were acceptable up to $7.5 \%$ black carrot concentrate incorporation, as the level was increased to $10 \%$ the liking scores decreased significantly (Table 3 ). The liking scores for other parameters viz., consistency, flavour, taste and overall acceptability established the same observations. The flavour and taste of black carrot concentrate became more prominent and peculiar at the $10 \%$ level which further affected all the sensory parameters. Therefore, yogurt sample with $7.5 \%$ black carrot concentrate was found as the best acceptable sample for further analysis.

The liking scores of all the experimental samples of buttermilk for sensory parameters viz., appearance, colour, consistency, flavour and taste were at par with control and showed high acceptability (Table 4). However, the overall acceptability of $10 \%$ black carrot concentrate was found to be the lowest. Therefore, buttermilk sample with $7.5 \%$ black carrot concentrate was selected and stored at refrigerated temperature $\left(4^{\circ} \mathrm{C}\right)$ in airtight glass bottles for further analysis. The sensory evaluation results pointed out that incorporation of black carrot concentrate in dairy products up to $7.5 \%$ gives the best overall acceptability. However, dairy products containing $10 \%$ black carrot concentrate were rated comparatively lower, which might be due to an excessive amount of polyphenolic compounds, which can negatively affect the sensory attributes of food (Drewnowski and Gomez- Carneros, 2000). The change in product colour was quite evident as represented in Fig 1. The initial colour of the products incorporated with $5 \%$ black carrot concentrate was reddish-purple, which became darker as the concentration increased. Experimental dairy products with $7.5 \%$ black carrot concentrate were analysed further along with control.

\subsection{Physicochemical properties}

Physicochemical properties of ice cream, yogurt and buttermilk with $7.5 \%$ black carrot concentrate are presented in Table 5. A significant increase in TSS ( ${ }^{\circ} \mathrm{Brix}$ ) was observed in all the experimental dairy products having $7.5 \%$ black carrot concentrate. This might be due to the higher TSS of black carrot concentrate ( $\left.40^{\circ} \mathrm{Brix}\right)$. The addition of black carrot concentrate $(7.5 \%)$ caused a significant increase in the acidity of the ice cream sample. This increase in acidity might be attributed to the acidity of black carrot concentrate. The results were in accordance with Kaur (2014) who reported that incorporation of ginger juice significantly $(p<0.01)$ increased the titratable acidity and decreased $\mathrm{pH}$ in ice cream. Hwang et al (2009) also reported similar results in grape wine lees incorporated ice cream. With respect to yogurt and buttermilk samples, incorporation of black carrot concentrate $(7.5 \%)$ showed significantly higher $\mathrm{pH}$ value and lower acidity than control. Higher pH and acidity could be due to the higher lactic acid content of the control. Mudgil and Barak (2016) who developed functional buttermilk by soluble fibre fortification also observed similar results.

\subsection{Mineral content}

The incorporation of black carrot concentrate into dairy products resulted in a significant increase in magnesium and iron content, however, zinc content was not affected (Fig 2). Mg content was found to be increased by $32 \%$ in ice cream, $57.9 \%$ in yogurt and $61.5 \%$ in buttermilk, whereas iron content increased from 1.4 times in ice cream to 6.5 times in buttermilk. The higher values of these estimated minerals in experimental buttermilk might be attributed to the higher content of respective minerals in black carrot (Nicolle et al 2004). These results suggested that black carrot concentrate could also be considered a good source of iron, which might help in combating anaemia, one of the biggest malnutrition problems of India. However, further study is required to assess their bioavailability. The promotion of such indigenous 
vegetables in diet might help alleviate food insecurity and malnutrition in developing countries (Kamga et al 2013).

\subsection{Anthocyanins, Flavonoids content and Folin-Ciocalteu reducing capacity:}

The major bioactive compound in black carrot is polyphenols and anthocyanins, which is well known for its colouring properties and strong antioxidant activity (Algarra et al 2014, Akhtar et al 2017, Pandey and Grover 2020). The total anthocyanin content of black carrot concentrate was $1682.66 \mathrm{mg} / 100 \mathrm{~g}$ and as expected the anthocyanins were detected only in dairy products containing black carrot concentrate (Table 6). The anthocyanin content of experimental dairy products ranged from 24.52 to $113.27 \mathrm{mg} / 100 \mathrm{~g}$. In recent years, the use of polyphenolic compounds such as anthocyanins has been extensively studied for their inhibitive effect in various chronic and degenerative diseases (Vauzour et al 2010). The pharmacological effect of anthocyanins compounds has been associated with their molecular structure. The suppressive effect of anthocyanins on oxidative stress-induced diseases and inhibition of inflammatory pathways have been established in several studies (Juránek and Bezek 2005, Zweier et al 1987). The strength of the antioxidant potential of anthocyanins depends on the total number of free hydroxyl group around the pyrone ring and the high number of hydroxyl groups dissipated throughout its molecular structure (Heymes et al 2003). Therefore, the incorporation of anthocyanin-rich black carrot concentrate in dairy products can result in additional health benefits. The flavonoids content of developed dairy products were also analyzed and results are shown in Table 6. The control samples represented a negligible amount of flavonoids, whereas experimental samples represented excellent content. This infers that dairy products possessed some amounts of polyphenols that are possibly derived from the milk. O'Connell and Fox (2001) reported 'phenolic compounds can be found in milk from animal feed, amino acid catabolism, and/or from the environment.' Polyphenols may also increase during the heating of milk due to Maillard's reaction. The flavonoids content of black carrot concentrate was reported to be $2314.22 \mathrm{mg} \mathrm{CE} / 100 \mathrm{~g}$ (Table 1). A comparison of the estimated content of polyphenols in dairy products and expected values suggested that some degradation might have occurred during processing. However, despite the loss of polyphenols after processing, all experimental dairy products containing black carrot concentrate showed significantly higher concentrations of phenols when compared with the control. The Folin-Ciocalteu reducing capacity of products showed a similar pattern as total flavonoid content. The reducing capacity increased significantly by 26-35 times upon incorporation of black carrot concentrate at 7.5\% level. The black carrot polyphenols are reported to possess better stability in comparison to other fruit polyphenols (Day et al. 2009). This feature offers black carrot as one of the most recommended natural sources of bioactive compounds such as anthocyanins.

\subsection{Total antioxidant capacity}

Total antioxidant capacity is a unique parameter that measures the strength of a sample to quench free radicals. The antioxidant activity of dairy products was greatly improved by the incorporation of black carrot concentrate. The total antioxidant capacity of all the experimental dairy products was significantly higher in comparison to control. The increase in antioxidant capacity was observed to be 7-8 times in ABTS assay 8-13 times in FRAP assay with the addition of black carrot concentrate at $7.5 \%$ into dairy products. High concentrations of polyphenols, flavonoids and anthocyanins in black carrot are the main contributors to their high antioxidant capacity. In addition, black carrot anthocyanins are more acylated which confers higher antioxidant activity than other monomeric anthocyanins (Kammerer et al 2004a). The results were in accordance with Cam et al (2013) who reported an increase in total antioxidant capacity with the addition of pomegranate peel phenolics and pomegranate seed oil in ice cream. Improvement in the antioxidant activity of the experimental sample 
might be attributed to the incorporation of polyphenols including anthocyanins, which had been proved to have high antioxidant properties (Grassmann et al 2007). These results are in agreement with Prior et al (1998) who demonstrated a linear relationship between antioxidant activity and total phenolic content. Both in vitro assays viz. ABTS and FRAP used for the analysis of the total antioxidant capacity of developed dairy products were found to be equally simple, economical and consistent. Presently, ABTS assay is the preferred method for analyzing the antioxidant capacity of anthocyanins containing samples, as the radical produced in this method has a maximum absorption at a wavelength of $734 \mathrm{~nm}$, therefore it reduces the chances of interference of anthocyanins which absorb between the wavelength of 460-550 nm (Kuskoski et al 2006). Prior et al (2005) and Van den Berg et al (1999) concluded that the antioxidant capacity assay can not truly reflect the "total antioxidant capacity" of phenolic products but it can be used to provide a ranking order of antioxidants.

\subsection{Storage stability}

Results in Table 7 shows the effect of storage on different quality attributes of experimental dairy products incorporated with $7.5 \%$ black carrot concentrate. A non-significant change in total solids, a significant increase in acidity and a decrease in $\mathrm{pH}$ was observed in ice cream during storage. The increase in acidity during storage might be due to the formation of lactic acid by lactic acid bacteria (Murtaza et al 2004). Bajwa et al (2003) also reported a decrease of $2.71 \%$ in pH value during 40 days of storage in ice cream containing strawberry pulp. During the storage period of 60 days, the total plate count of ice cream decreased significantly from 3.33 to $1.82 \log _{10} \mathrm{cfu} / \mathrm{g}$. The reduction in the total plate count (TPC) was due to the destruction of bacteria at low temperatures. The TPC values for the ice cream samples were within the acceptable levels as per ISI specifications i.e. $250 \log _{10}$ cfu/ml maximum (De 2006). This might be attributed to the formation of ice crystals which disrupts the cell membrane of microbes resulting in a decrease in microbial load (Davidson et al 2000). Black carrot concentrate also had a high antioxidant capacity, which prevents oxidation of fat thus increases the shelf life of the product. Goraya (2013) also reported a decline in TPC of ice cream with amla products during the storage period of 60 days. Yeasts and moulds were not detected throughout the 2 months of the storage study, however, a gradual decrease in overall acceptability scores of all the ice cream samples (8.25 to 7.89) was reported. However, scores were found to be in a highly acceptable range throughout the period.

For fermented dairy products, $\mathrm{pH}$ and acidity are key quality defining parameters as they determine their organoleptic properties, shelf-life quality and microbial safety. The $\mathrm{pH}$ values of the yogurt sample declined significantly from 4.52 to 3.73 after the $15^{\text {th }}$ day of storage. The acidity values gradually increased from 0.51 to $0.61 \%$ during the storage in black carrot concentrate added yogurt after 15 days of storage. Beal et al (2001) observed an increased production of lactic acid and galactose in the first 2 weeks due to increased microbial metabolic activity with lactose utilization by lactic acid bacteria. There was a significant reduction in TPC in yogurt sample due to a lower pH and higher acidic processing conditions during storage. A decline in the number of lactobacilli bacteria was also reported in fruit yogurt during storage by Canganella et al (1998) and Vahedi et al (2008). The probiotic bacteria must reach the intestine in an active state and in adequate quantities i.e. 6-7 $\log _{10} \mathrm{cfu} / \mathrm{g}$ of product in order to exert health benefits. The black carrot concentrate enriched yogurts maintained recommended probiotic quantity up to ten days of storage period at $4{ }^{\circ} \mathrm{C}$. Yeast and mould counts were not identified over the storage period of yogurt sample. The overall acceptability scores of the yogurt samples declined significantly after 5 days of storage. Thus, best acceptability up to 5 days could be considered for yogurt. The 
decline in overall acceptability might be attributed to the increased acidity of yogurt during storage.

The acidity of buttermilk sample increased significantly till the 15th day of storage. The results were in line with Patel et al (2017) who observed a rise in acidity of buttermilk samples during storage at refrigerated condition. pH values of buttermilk showed a gradual decline during the storage at $4^{\circ} \mathrm{C}$. Rao (2003) also reported a decrease in pH of buttermilk samples from an initial value of 4.14 to 4.11 on the $12^{\text {th }}$ day of storage. During storage of buttermilk, a significant rise in the TPC value was reported up to the $15 \mathrm{t}^{\mathrm{t}}$ day from 4.16 to $4.36 \log _{10} \mathrm{cfu} / \mathrm{g}$. A steady rise in TPC was also observed by Patel et al (2017) during storage of buttermilk supplemented with Moringa. Yeast and mould counts were not identified in the experimental buttermilk sample throughout the storage period. A decrease in scores for overall acceptability of the buttermilk samples was observed throughout the storage period, which dropped significantly after 10 days of storage (7.30). The decline in overall acceptability was attributed to the increased acidity of buttermilk during storage. Thus, it can be concluded that $7.5 \%$ black carrot concentrate enriched buttermilk can be well accepted up to 10 days of storage at $4^{0} \mathrm{C}$ temperature.

\section{Conclusion}

In this study, black carrot concentrate enriched dairy products were developed and analysed for sensory attributes, physicochemical characteristics, polyphenols and antioxidant capacity and storage stability. The results showed that black carrot concentrate at the level of $7.5 \%$ could be used in the development of acceptable dairy products. The incorporation of black carrot concentrate markedly increased the total anthocyanin, total phenols, total flavonoids, antioxidant activity, magnesium and iron content of dairy products without significantly affecting their sensory attributes. We may also infer that the 'Punjab Black Beauty' variety of Indian black carrot can be meritoriously incorporated into dairy products to exhibit higher bioactive compounds, antioxidant activity and mineral content.

\section{Acknowledgement}

The author would like to thank Dr Mudit Chandra (Assistant Scientist, Department of Veterinary Microbiology, College of Veterinary Science, GDVASU, Ludhiana Punjab, India) for supporting to carry out microbiological work of this paper in their lab.

\section{Reference:}

Akhtar, S., Rauf, A., Imran, M., Qamar, M., Riaz, M., \& Mubarak, M. S. (2017). Black carrot (Daucus carota L.), dietary and health promoting perspectives of its polyphenols: A review. Trends in Food Science \& Technology, 66, 36-47.

Algarra M, Fernandes A, Mateus N, Freitas V, Joaquim C G, Silva E D and Casado J (2014) Anthocyanin profile and antioxidant capacity of black carrots (Daucus carota L. ssp. sativus var. atrorubens Alef.) from Cuevas Bajas, Spain. J Food Composition Anal 33: 71-76.

AOAC International (2010) Official Methods of Analysis (18 $\left.{ }^{\text {th }} \mathrm{ed}\right)$. Association of Official Analytical Chemists, Washington DC.

Bajwa, U. A., Huma, N., Ehsan, B., Jabbar, K., \&Khurrama, A. (2003). Effect of different concentration of strawberry pulp on the properties of ice cream. Int J AgricBiol, 15, 635-637.

Béal, C., Fonseca, F., \& Corrieu, G. (2001). Resistance to freezing and frozen storage of Streptococcus thermophiles is related to membrane fatty acid composition. Journal of Dairy Science, 84(11), 2347-2356.

Benzie, I. F., \& Strain, J. J. (1999). [2] Ferric reducing/antioxidant power assay: direct measure of total antioxidant activity of 
biological fluids and modified version for simultaneous measurement of total antioxidant power and ascorbic acid concentration. Methods in enzymology, 299, 15-27.

Cam M, Erdogan F, Aslan D and Dinc M (2013) Enrichment of functional properties of ice cream with pomegranate byproducts. J Food Sci 10: 1543-50.

Canganella, F., Ovidi, M., Paganini, S., Vettraino, A. M., Bevilacqua, L., \&Trovatelli, L. D. (1998). Survival of undesirable micro-organisms in fruit yogurts during storage at different temperatures. Food Microbiology, 15(1), 71-77.

Costa, C., Tsatsakis, A., Mamoulakis, C., Teodoro, M., Briguglio, G., Caruso, E, Tsoukalas, D., Margina, D., Dardiotis, E., Kouretas, D. \& Fenga, C. (2017). Current evidence on the effect of dietary polyphenols intake on chronic diseases. Food and Chemical Toxicology, 110, 286-299.

Daniel Granato, Jânio Sousa Santos, Laércio Galvão Maciel, Domingos Sávio Nunes, Chemical perspective and criticism on selected analytical methods used to estimate the total content of phenolic compounds in food matrices, Trends in Analytical Chemistry (2016), http://dx.doi.org/doi: 10.1016/j.trac.2016.03.010.

David B and Frankhausar (2015) Pour plate technique for bacterial enumeration (Cited from http://biology.clc.uc.edu/frankhauser/Labs/Microbiology/Meat Milk/Pour Plate.html)

Davidson, R. H., Duncan, S. E., Hackney, C. R., Eigel, W. N., \& Boling, J. W. (2000). Probiotic culture survival and implications in fermented frozen yogurt characteristics. Journal of dairy science, 83(4), 666-673.

Day L, Seymour RB, Pitts KF et al (2009) Incorporation of functional ingredients into foods. Trends Food Sci Technol 20:388-395.

De S (2006) Outlines of Dairy Technology:Ice cream. Pp 182-83. Oxford University Press $1^{\text {st }}$ edn. New Delhi.

Drewnowski, A., \& Gomez-Carneros, C. (2000). Bitter taste, phytonutrients, and the consumer: A review. American Journal of Clinical Nutrition, 72, 1424-1435.

David B and Frankhausar (2015) Pour plate technique for bacterial enumeration (Cited from http://biology.clc.uc.edu/frankhauser/Labs/Microbiology/Meat_Milk/Pour_Plate.html).

Glei M, Matuschek M, Steiner C, Bohm V, Persin C and Pool-Zobel B L (2003) Initial in vitro toxicity testing of functional foods rich in catechins and anthocyanins in human cells. Toxicol in Vitro 17: 723-29.

Goraya R K (2013) Functionality and quality assessment of amla incorporated ice cream. M.Sc. thesis, Punjab Agricultural University, Ludhiana, India.

Grassmann J, Schnitzler WH, Habegger R (2007) Evaluation of different coloured carrot cultivars on antioxidative capacity based on their carotenoid and phenolic contents. Int J Food SciNutr 58:603-611.

Hashim, I., \& Shamsi, K. S. A. (2016). Physiochemical and sensory properties of ice-cream sweetened with date syrup. MOJ Food Process Technol, 2(3), 1-4.

Heymes C, Bendall JK, Ratajczak P, Cave AC, Samuel J-L, Hasenfuss G, et al. Increased myocardial NADPH oxidase activity in human heart failure. J Am CollCardiol. 2003;41:2164-2171. doi: 10.1016/S0735 1097(03)00471-6.

Hwang, J. Y., Shyu, Y. S., \& Hsu, C. K. (2009). Grape wine lees improves the rheological and adds antioxidant properties to ice cream. LWT-Food Science and Technology, 42(1), 312-318.

Juránek I, Bezek S. Controversy of free radical hypothesis: reactive oxygen species-cause or consequence of tissue injury? Gen Physiol Biophys. 2005;24:263-278.. 
Kamga, R. T., Kouamé, C., Atangana, A. R., Chagomoka, T., \& Ndango, R. (2013). Nutritional evaluation of five African indigenous vegetables. Journal of Horticultural Research, 21(1), 99-106.

Kammerer D, Carle R, Schieber A. Characterization of phenolic acids in black carrots (Daucus carota ssp. sativus var. atrorubens Alef.) by high performance liquid chromatography/electrospray ionization mass spectrometry. Rapid Commun in Mass Spectrom. 2004; 18:1331-40.

Karakaya S, EI SN and Tas AA (2001) Antioxidant activity of some food containing phenolic compounds. Int J Food Sci Nutr 52: 501-08.

Kaur C and Kapoor H C (2002) Antioxidant activity and total phenolic content of some Asian vegetables. Intl J Food Sci Techno/37:153-61.

Kaur, D. (2014). Assessment of quality and stability of ginger incorporated ice cream (Doctoral dissertation, Punjab Agricultural University, Ludhiana).

Keskin-Šašić, I., Tahirović, I., Topčagić, A., Klepo, L., Salihović, M. B., Ibragić, S., ... \& Velispahić, E. (2012). Total phenolic content and antioxidant capacity of fruit juices. Bulletin of the Chemists and Technologists of Bosnia and Herzegovina, 39, 25-28.

Kuskoski EM, Asuero AG, Troncoso AM, Fett R. Antioxidant activity of pulps of tropical fruits. Application of the ABTS method. Alimentaria 2006; 376: 67-70.

L.Y. Chen, C.W. Cheng, J.Y. Liang, Effect of esterification condensation on the Folin-Ciocalteu method for the quantitative measurement of total phenols, Food Chem. 170 (2015) 10-15.

Larmond, E. (1970). Methods for sensory evaluation of food. Publication 1284. Food Research Institute, Central Experimental Farm, Canada Department of Agriculture, Ottawa, Canada.

Marques, M. R., Paz, D. D., Batista, L. P. R., Barbosa, C. D. O., Araújo, M. A. M., \& Moreira-Araújo, R. S. D. R. (2012). An in vitro analysis of the total phenolic content, antioxidant power, physical, physicochemical, and chemical composition of Terminalia Catappa Linn fruits. Food Science and Technology, 32(1), 209-213.

Mudgil, D., \& Barak, S. (2016). Development of functional buttermilk by soluble fibre fortification. Agro Food Industry Hi Tech, 27(2), 44-47.

Murtaza, M. A., Huma, N. U. Z. H. A. T., Mueen-Ud-Din, G., Shabbir, M. A., \& Mahmood, S. H. A. H. I. D. (2004). Effect of fat replacement by fig addition on ice cream quality. Int J AgricBiol, 6(1), 68-70.

Miller, N. J., \& Rice-Evans, C. (1997). Factors influencing the antioxidant activity determined by the ABTS •+ radical cation assay. Free Radical Research, 26, 195-199.

Nabavi S F, Nabavi S M, Setzer W N, Nabavi S, Nabavi S A and Ebrahimzadeh M A (2013) Antioxidant and antihemolytic activity of lipid-soluble bioactive substances in avocado fruits. Fruits 68: 185-93.

Narayan M S and Vankataraman L V (2000) Characterization of anthocyanins derived from carrot (Daucus carota) cell culture. Food Chem70: 361-63.

Nicolle, C., Simon, G., Rock, E., Amouroux, P., \& Rémésy, C. (2004). Genetic variability influences carotenoid, vitamin, phenolic, and mineral content in white, yellow, purple, orange, and dark-orange carrot cultivars. Journal of the American Society for Horticultural Science, 129(4), 523-529.

O'connell, J. E., \& Fox, P. F. (2001). Significance and applications of phenolic compounds in the production and quality of 
milk and dairy products: a review. International Dairy Journal, 11(3), 103-120.

Pandey, K. B., \& Rizvi, S. I. (2009). Plant polyphenols as dietary antioxidants in human health and disease. Oxidative medicine and cellular longevity, 2.

Pandey, P., \& Grover, K. (2020). Characterization of black carrot (Daucus carota L.) polyphenols; role in health promotion and disease prevention: An overview. Journal of Pharmacognosy and Phytochemistry, 9(5), 2784-2792.

Patel, B. K., Patel, S. M., Modi, Z. S., \& Pinto, S. V. (2017). Shelf Life Studies of buttermilk supplemented with Moringa. Int J Curr Microbiol App Sci, 6(4), 552-67.

Piper, C. S. (1950). Soil and plant analysis. Interscience Pub. Inc., New York. Pp. 212

Prior, R. L., Cao, G., Martin, A., Sofic, E., McEwen, J., O'Brien, C, Lischner, N., Ehlenfeldt, M., Kalt, W., Krewer G., \& Mainland, C. M. (1998). Antioxidant capacity as influenced by total phenolic and anthocyanin content, maturity, and variety of Vaccinium species. Journal of agricultural and food chemistry, 46(7), 2686-2693.

Prior, R. L., Wu, X., \& Schaich, K. (2005). Standardized methods for the determination of antioxidant capacity and phenolics in foods and dietary supplements. Journal of agricultural and food chemistry, 53(10), 4290-4302.

Rabino I, Mancinelli AL and Kuzmanoff KM (1977) Photocontrol of anthocyanin synthesis: VI. Spectral sensitivity, irradiance dependence, and reciprocity relationships. Plant Physiology 59: 569-73.

Ranganna, S. (1997). Handbook of analysis and quality control for fruit and vegetable products. Tata McGraw-Hill Education. Pp. 47-48

Rao, A. V. (2003). Selected technological parameters for manufacture of chhash (M. Sc. Thesis submitted to Anand Agricultural University, Anand).

Ravindra P V and Narayan M S (2003) Antioxidant activity of the anthocyanin from carrot (Daucus carota) callus culture. Intl J Food Sci Nutr 54: 349-55.

Swain, T., \& Hillis, W. E. (1959). The phenolic constituents of Prunusdomestica. I.-The quantitative analysis of phenolic constituents. Journal of the Science of Food and Agriculture, 10(1), 63-68.

Uttara, B., Singh, A. V., Zamboni, P., \& Mahajan, R. T. (2009). Oxidative stress and neurodegenerative diseases: a review of upstream and downstream antioxidant therapeutic options. Current neuropharmacology, 7(1), 65-74.

Uyan S E, Baysal T, Yurdagel Ü and EI S N (2004) Effects of drying process on antioxidant activity of purple carrots. Food/Nahrung 48: 57-60.

Vahedi N, Tehrani M M and Shahidi F (2008) Optimizing of fruit yoghurt formulation and evaluating its quality during storage. Am-Eurasian J Agric Environ Sci 3: 922-27.

Van den Berg, R., Haenen, G. R., van den Berg, H., \& Bast, A. A. L. T. (1999). Applicability of an improved Trolox equivalent antioxidant capacity (TEAC) assay for evaluation of antioxidant capacity measurements of mixtures. Food Chemistry, 66(4), 511-517.

Vauzour D, Rodriguez-Mateos A, Corona G, Oruna-Concha MJ, Spencer JPE. Polyphenols and human health: prevention of disease and mechanisms of action. Nutrients. 2010;2:1106-1131. doi: 10.3390/nu2111106.

Vizzotto, M., Cisneros-Zevallos, L., Byrne, D. H., Ramming, D. W., \& Okie, W. R. (2006). Total phenolic, carotenoid, and anthocyanin content and antioxidant activity of peach and plum genotypes.

Xiao J, Capanoglu E, Jassbi A R and Miron A (2014). The paradox of natural flavonoid C-glycosides and health benefits: 
When more occurrence is less research. Biotechnol Adv (14) (Cited from

http://dx.doi.org/10.1016/j.biotechadv.2014.11.002).

Xiao J, Chen T and Cao H (2014a) Flavonoid glycosylation and biological benefits. Biotechnol Adv (14) (Cited from http://dx.doi.org/10.1016/j.biotechadv.2014.05.004)

Xiao J, Ni X, Kai G and Chen X (2015) Advance in dietary polyphenols as aldose reductases inhibitors: Structure-activity relationship aspect. Crit Rev Food Sci Nutr 55: 16-31.

Zhishen, J., Mengcheng, T., \& Jianming, W. (1999). The determination of flavonoid contents in mulberry and their scavenging effects on superoxide radicals. Food chemistry, 64(4), 555-559.

Zweier JL, Flaherty JT, Weisfeldt ML. Direct measurement of free radical generation following reperfusion of ischemic myocardium. Proc Natl AcadSci USA. 1987;84:1404-1407.doi: 10.1073/pnas.84.5.1404.

Mancinelli, A. L., Yang, C. P. H., Lindquist, P., Anderson, O. R., \& Rabino, I. (1975). Photocontrol of anthocyanin synthesis: III. The action of streptomycin on the synthesis of chlorophyll and anthocyanin. Plant physiology, 55(2), 251-257.

Table 1. Physicochemical, Polyphenolic content and antioxidant activity of black carrot concentrate

\begin{tabular}{|c|c|c|c|c|c|c|c|}
\hline & & & & & & Total antioxic & apacity \\
\hline & TSS ( ${ }^{0}$ Brix $)$ & $\begin{array}{l}\text { Acidity } \\
(\mathrm{mg} / 100 \mathrm{~g})\end{array}$ & $\begin{array}{l}\text { Total Flavonoids (mg } \\
\text { CE/100g) }\end{array}$ & $\begin{array}{l}\text { Anthocyanins } \\
(\mathrm{mg} / 100 \mathrm{~g})\end{array}$ & $\begin{array}{l}\text { capacity } \\
\text { (mg GAE/100g) }\end{array}$ & $\begin{array}{l}\text { ABTS assay } \\
(\mu \mathrm{molTE} / \mathrm{g})\end{array}$ & $\begin{array}{l}\text { FRAP assay } \\
(\mu \mathrm{molTE} / \mathrm{g})\end{array}$ \\
\hline Black carrot Raw & $8.00 \pm 0.10$ & $0.25 \pm 0.01$ & $82.73 \pm 1.62$ & $233.32 \pm 11.14$ & $283.53 \pm 5.50$ & $21.79 \pm 1.03$ & $12.28 \pm 0.41$ \\
\hline $\begin{array}{l}\text { Black carrot } \\
\text { concentrate }\end{array}$ & $40.02 \pm 2.70$ & $1.29 \pm 0.12$ & $2314.22 \pm 73.16$ & $1682.66 \pm 35.69$ & $8571.90 \pm 25.64$ & $31.33 \pm 1.26$ & $23.32 \pm 0.87$ \\
\hline
\end{tabular}

Data are mean \pm SD $(n=3)$.

FRAP (ferric reducing antioxidant power).

ABTS (2,2'-azino-bis(3-ethylbenzothiazoline-6-sulfonic acid)

Table 2. Sensory analysis of black carrot concentrate incorporated ice cream

\begin{tabular}{|c|c|c|c|c|c|c|c|}
\hline \multicolumn{2}{|l|}{ Ice cream } & Appearance & Colour & Texture & Flavour & Taste & Overall acceptability \\
\hline \multicolumn{2}{|l|}{ Control } & 8.50 & 8.30 & 8.20 & 8.10 & 8.00 & 8.10 \\
\hline \multirow{3}{*}{ Experimental } & $5.0 \%$ & 8.30 & 8.10 & 8.25 & 8.00 & 8.05 & 8.20 \\
\hline & $7.5 \%$ & 8.50 & 8.45 & 8.30 & 8.01 & 8.20 & 8.25 \\
\hline & $10.0 \%$ & 8.35 & 8.00 & 8.10 & 7.80 & 7.70 & 7.50 \\
\hline \multicolumn{2}{|c|}{$\begin{array}{l}\text { X2 value } \\
\text { (Kruskal-Wallis test) }\end{array}$} & $12.29^{*}$ & $10.10^{*}$ & $1.23^{\mathrm{NS}}$ & $9.52^{*}$ & $11.73^{\star}$ & $9.71^{*}$ \\
\hline
\end{tabular}

** Significant at $1 \%$ level of significance $(p<0.01)$ *Significant at $5 \%$ level of significance $(p<0.05)$, NS - Non-significant, Control - Product developed with standard recipe,

Experimental- product developed by incorporating black carrot concentrate at different levels into standard recipe.

Table 3. Sensory analysis of black carrot concentrate incorporated yogurt 


\begin{tabular}{|l|l|l|l|l|l|l|l|}
\hline Yogurt & & Appearance & Colour & Consistency & Flavour & Taste & Overall acceptability \\
\hline Control & & 8.50 & 8.50 & 8.50 & 8.20 & 8.15 & 8.20 \\
\hline & $5.0 \%$ & 8.10 & 8.20 & 8.10 & 7.85 & 8.05 & 8.00 \\
\hline Experimental & $7.5 \%$ & 8.00 & 7.80 & 8.00 & 7.80 & 7.85 & 7.80 \\
\hline & $10.0 \%$ & 6.50 & 6.60 & 6.50 & 6.40 & 6.65 & 6.50 \\
\hline $\begin{array}{l}\text { X2 value } \\
\text { (Kruskal-Wallis test) }\end{array}$ & $18.06^{*}$ & & $20.47^{* *}$ & $14.02^{* *}$ & $12.85^{* *}$ & $12.54^{* *}$ & $15.42^{* *}$ \\
\hline
\end{tabular}

** Significant at $1 \%$ level of significance $(p<0.01)$ *Significant at $5 \%$ level of significance $(p<0.05)$, NS - Non-significant, Control - Product developed with standard recipe,

Experimental- product developed by incorporating black carrot concentrate at different levels into standard recipe.

\section{Table 4. Sensory analysis of black carrot concentrate incorporated buttermilk}

\begin{tabular}{|l|l|l|l|l|l|l|l|}
\hline Buttermilk & & Appearance & Colour & Consistency & Flavour & Taste & Overall acceptability \\
\hline Control & & 8.00 & 8.20 & 8.30 & 8.05 & 8.50 & 8.10 \\
\hline & $5.0 \%$ & 8.20 & 8.40 & 8.25 & 8.10 & 8.30 & 8.20 \\
\hline Experimental & $7.5 \%$ & 8.25 & 8.35 & 8.35 & 8.20 & 8.50 & 8.40 \\
\hline & $10.0 \%$ & 8.00 & 8.05 & 8.15 & 7.80 & 8.10 & 7.80 \\
\hline $\begin{array}{l}\text { X2 value } \\
\text { (Kruskal-Wallis test) }\end{array}$ & $1.11^{\text {NS }}$ & $0.63^{\mathrm{NS}}$ & $1.60^{\mathrm{NS}}$ & $5.60^{\mathrm{NS}}$ & $1.31^{\mathrm{NS}}$ & $8.58^{*}$ \\
\hline
\end{tabular}

** Significant at $1 \%$ level of significance $(p<0.01)$ *Significant at $5 \%$ level of significance $(p<0.05)$, NS - Non-significant, Control - Product developed with standard recipe,

Experimental- product developed by incorporating black carrot concentrate at different levels into standard recipe.

Table 5. Physicochemical characteristics of black carrot concentrate incorporated dairy products

\begin{tabular}{|c|c|c|c|c|}
\hline \multicolumn{2}{|l|}{ Products } & TSS $\left({ }^{0}\right.$ brix $)$ & $\begin{array}{l}\text { Acidity } \\
\text { (\% Lactic Acid) }\end{array}$ & $\mathrm{pH}$ \\
\hline \multirow{3}{*}{ Ice cream } & Control & $25.38 \pm 0.34$ & $0.16 \pm 0.00$ & $6.60 \pm 0.10$ \\
\hline & Experimental (7.5\%) & $26.86 \pm 0.51$ & $0.23 \pm 0.01$ & $6.41 \pm 0.09$ \\
\hline & t-value & $4.18^{*}$ & $7.56^{\star *}$ & $2.43^{\mathrm{NS}}$ \\
\hline \multirow{3}{*}{ Yogurt } & Control & $8.11 \pm 0.30$ & $0.61 \pm 0.03$ & $4.13 \pm 0.02$ \\
\hline & Experimental $(7.5 \%)$ & $10.30 \pm 0.70$ & $0.51 \pm 0.05$ & $4.52 \pm 0.19$ \\
\hline & t-value & $4.98^{\star *}$ & $2.97^{*}$ & $3.54^{*}$ \\
\hline \multirow{3}{*}{ Buttermilk } & Control & $1.60 \pm 0.07$ & $0.62 \pm 0.01$ & $4.83 \pm 0.01$ \\
\hline & Experimental (7.5\%) & $2.50 \pm 0.10$ & $0.58 \pm 0.01$ & $4.96 \pm 0.01$ \\
\hline & t-value & $12.77^{\star *}$ & $4.90^{* *}$ & $14.70^{\star *}$ \\
\hline
\end{tabular}

** Significant at $1 \%$ level of significance $(p<0.01)$, *Significant at $5 \%$ level of significance $(p<0.05)$, NS - Non significant, 
Control - Product developed with standard recipe,

Experimental- Product developed by incorporating $7.5 \%$ black carrot concentrate into the standard recipe

Table 6. Polyphenols content and antioxidant activity of black carrot concentrate incorporated dairy products

\begin{tabular}{|c|c|c|c|c|c|c|}
\hline \multirow{2}{*}{ Products } & & \multirow{2}{*}{$\begin{array}{l}\text { Anthocyanin } \\
\text { (mg/100g) }\end{array}$} & \multirow{2}{*}{$\begin{array}{l}\text { Total Flavonoids } \\
\text { (mg CE } / 100 \mathrm{~g} \text { ) }\end{array}$} & \multirow{2}{*}{ Folin-Ciocalteu reducing capacity (mg GAE/100g) } & \multicolumn{2}{|c|}{ Total antioxidant capacity } \\
\hline & & & & & ABTS $(\mu \mathrm{molTE} / \mathrm{g})$ & FRAP $(\mu \mathrm{mol} \mathrm{TE} / \mathrm{g})$ \\
\hline \multirow{3}{*}{ Ice cream } & Control & ND & $4.02 \pm 0.96$ & $14.32 \pm 1.32$ & $3.01 \pm 0.03$ & $1.01 \pm 0.02$ \\
\hline & Experimental & $98.09 \pm 11.31$ & $139.21 \pm 12.33$ & $513.63 \pm 57.15$ & $24.64 \pm 0.49$ & $13.48 \pm 0.34$ \\
\hline & t-value & $15.02^{\star *}$ & $18.93^{\star *}$ & $15.13^{\star *}$ & $76.61^{\star *}$ & $63.98^{\star *}$ \\
\hline \multirow{3}{*}{ Yogurt } & Control & ND & $10.36 \pm 0.93$ & $19.36 \pm 1.03$ & $3.53 \pm 0.02$ & $1.57 \pm 0.02$ \\
\hline & Experimental & $113.27 \pm 10.41$ & $165.91 \pm 18.39$ & $544.30 \pm 61.99$ & $25.31 \pm 0.33$ & $13.94 \pm 0.33$ \\
\hline & t-value & $18.85^{\star *}$ & $14.63^{\star *}$ & $14.67^{\star *}$ & $115.76^{\star *}$ & $65.81^{\star *}$ \\
\hline \multirow{3}{*}{ Buttermilk } & Control & ND & $2.23 \pm 0.44$ & $4.44 \pm 0.86$ & $2.08 \pm 0.07$ & $0.83 \pm 0.04$ \\
\hline & Experimental & $24.52 \pm 2.41$ & $32.39 \pm 2.56$ & $117.19 \pm 11.26$ & $15.11 \pm 0.1$ & $7.03 \pm 0.14$ \\
\hline & t-value & $17.62^{* *}$ & $20.11^{* *}$ & $17.29^{* *}$ & $184.16^{\star *}$ & $74.34^{\star *}$ \\
\hline
\end{tabular}

Data are mean $\pm S D(n=3)$.

** Significant at $1 \%$ level of significance $(p<0.01)$, *Significant at $5 \%$ level of significance $(p<0.05)$, NS - Non significant, Control - Product developed with standard recipe,

Experimental- Product developed by incorporating 7.5\% black carrot concentrate into the standard recipe ND: Not detectible

FRAP (Ferric reducing antioxidant power).

ABTS (2,2'-azino-bis(3-ethylbenzothiazoline-6-sulfonic acid)

Table 7. Effect of storage on physicochemical, microbial and sensory attributes of black carrot concentrate incorporated dairy products 
Storage period (days) Total solids (\%) $\mathrm{pH}$ Ice cream

15

30

45

60

Yogurt

\begin{tabular}{|c|c|c|c|c|c|}
\hline & $\mathrm{pH}$ & Acidity (\%) & $\begin{array}{l}\text { TPC } \\
\left(\log _{10} \mathrm{cfu} / \mathrm{g}\right)\end{array}$ & $\begin{array}{l}\text { YMC } \\
\left(\log _{10} \mathrm{cfu} / \mathrm{g}\right)\end{array}$ & Overall acceptability \\
\hline 0 & $4.52 \pm 0.06^{\mathrm{a}}$ & $0.51 \pm 0.01^{\mathrm{a}}$ & $8.90 \pm 0.01^{a}$ & ND & $7.80 \pm 0.05^{\mathrm{a}}$ \\
\hline 5 & $4.10 \pm 0.02^{b}$ & $0.53 \pm 0.01^{a}$ & $7.75 \pm 0.02^{b}$ & ND & $7.65 \pm 0.06^{b}$ \\
\hline 10 & $3.85 \pm 0.06^{c}$ & $0.57 \pm 0.01^{b}$ & $6.60 \pm 0.04^{c}$ & ND & $6.80 \pm 0.10^{c}$ \\
\hline \multicolumn{6}{|c|}{ Buttermilk } \\
\hline & $\mathrm{pH}$ & Acidity (\%) & $\begin{array}{l}\text { TPC } \\
\left(\log _{10} \mathrm{cfu} / \mathrm{g}\right)\end{array}$ & $\begin{array}{l}\text { YMC } \\
\left(\log _{10} \mathrm{cfu} / \mathrm{g}\right)\end{array}$ & Overall acceptability \\
\hline 10 & $4.01 \pm 0.01^{b}$ & $0.39 \pm 0.01^{a}$ & $4.35 \pm 0.01^{b}$ & ND & $7.30 \pm 0.02^{c}$ \\
\hline 15 & $3.84 \pm 0.01^{a}$ & $0.42 \pm 0.01^{a}$ & $4.39 \pm 0.01^{a}$ & ND & $6.80 \pm 0.05^{d}$ \\
\hline
\end{tabular}

Value are mean $\pm S D$, Value in columns followed by different superscript differ significantly at $5 \%$ level. ND- Not Detectable

Ice cream, Yogurt and Buttermilk sample contain $7.5 \%$ black carrot concentrate

TPC: Total Plate count

YMC: Yeast and mould count 
(A)

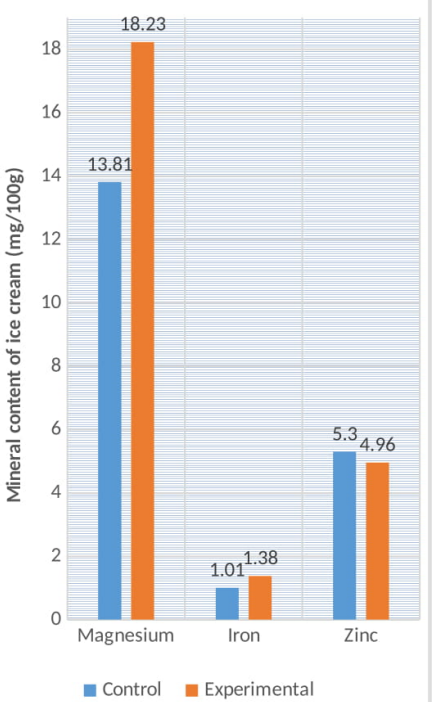

(B)

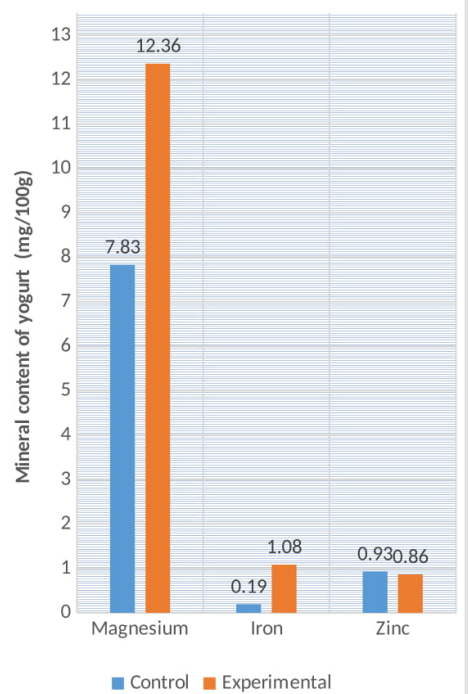

(C)

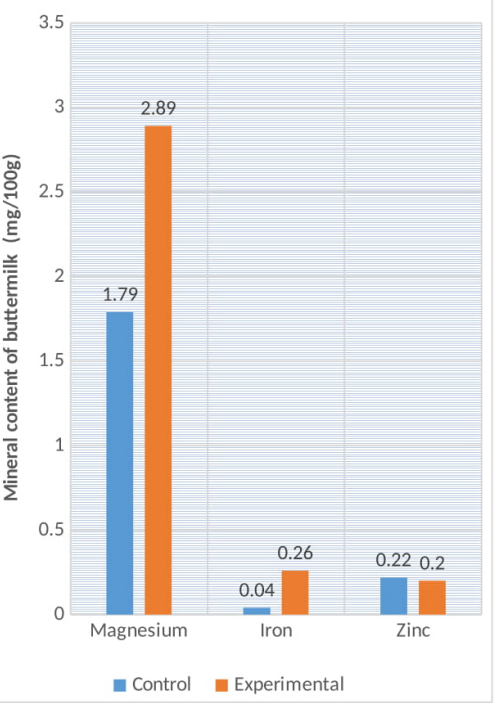

32Figure 2. Mineral content of black carrot concentrate incorporated dairy products. Ice cream prepared by incorporating black carrot concentrate (A); Yogurt 33prepared by incorporating black carrot concentrate (B); Buttermilk prepared by incorporating black carrot concentrate (C). Control- Standard product; 34Experimental- Product developed by incorporating $7.5 \%$ black carrot concentrate into the standard recipe. Values are expressed on fresh weight basis. Bars 35represent standard deviation of means $(\mathrm{n}=3)$.

36 


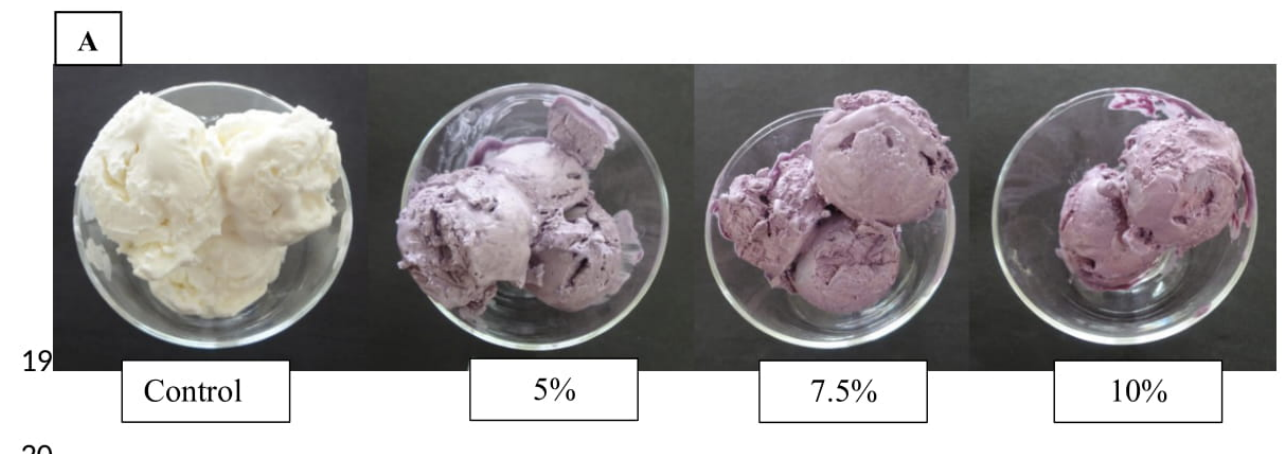

20

21
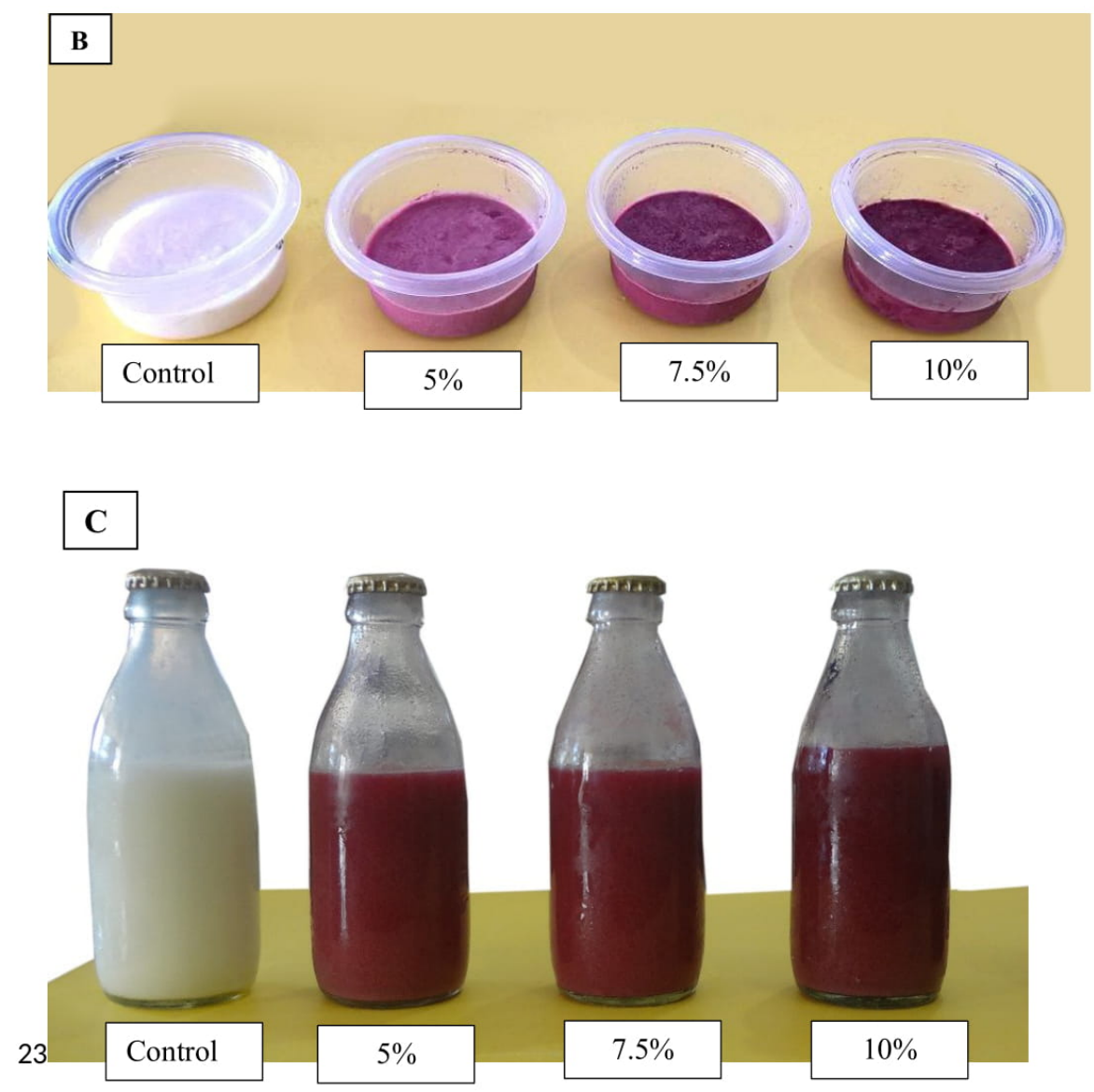

24

25Figure 1. Representation of dairy products developed by incorporating black carrot concentrate; Ice cream prepared 26by incorporating black carrot concentrate (A); Yogurt prepared by incorporating black carrot concentrate (B); 27Buttermilk prepared by incorporating black carrot concentrate (C). Control- Standard product; 5\%- product 28developed by incorporating $5 \%$ black carrot concentrate; $7.5 \%$ - product developed by incorporating $7.5 \%$ black 29 carrot concentrate; $10 \%$ - product developed by incorporating $10 \%$ black carrot concentrate 
